\title{
Peopled landscapes: The impact of Peter Kershaw on Australian Quaternary science
}

\section{Bruno David}

School of Geography and Environmental Science, Monash University, Clayton, Victoria bruno.david@monash.edu

\section{Simon G. Haberle}

The Australian National University, Canberra, ACT

\section{Donald Walker}

The Australian National University, Canberra, ACT

"I don't think the buman mind can comprehend the past and the future. They are both just illusions that can manipulate you into thinking there's some kind of change."

Bob Dylan (Ft. Lauderdale Sun-Sentinel Interview, 28 September 1995).

\section{Introduction}

The way we view the Australian landscape at the start of the 21st century is notably different to how we viewed it in the late 20th century, and Peter Kershaw has had a most significant role in this. One of the key elements to Peter's intellectual contribution lies in the discovery that the Australian landscape is more changeable and dynamic than was previously imagined, and in particular more deeply influenced by human history than we could have then known. The notion that people arriving in an uninhabited landscape over 40,000 years ago so fundamentally changed fire regimes, and that Aboriginal people have continued to shape the environment through ongoing landscape firing practices ever since - and as a consequence affected the whole ecology of an island continent - is one that shook the scientific community and forced a rethink of the way we view the long-term history and present environmental 
state of Australia. The impacts of this on the broader Australian and international community have contributed to a critical rethinking of political paradigms and conservationist policies and their articulation with Indigenous perspectives on landscape, especially as these relate to fire management (e.g. Hale and Lamb 1997); indeed, in the mid-1990s the Australian Conservation Foundation's general approach to landscape management radically shifted to take better account of Indigenous concerns, together with Indigenous voices a result of the accumulated wisdom of previous years of palaeoecological research that by then demanded consideration of the role of people in landscape management. These were precisely the kinds of issues spurred by Peter's findings in north Queensland and elsewhere, research results that had shown to be critical to understanding the Australian environment today as in the past. Thus while throughout his career Peter himself has been more directly concerned with gathering evidence towards establishing the facts of Australia's landscape history, those results have influentially fed back into community perspectives, political dialogue and policy-making. Peter's work continues to engage both the scientific community and the public in an ongoing debate over the role of people in shaping the environment.

The investigation that contributed most to the shift in our understanding of the role of people in Australian landscapes was based around a pollen record from Lynch's Crater (Figure 1) in northeast Australia (Kershaw 1974). Peter began working on this long environmental record for his PhD thesis (Kershaw 1973) in the Department of Biogeography and Geomorphology at the Australian National University (ANU) in the early 1970s, at a time when palaeoecological research in Australia was in its infancy. In 1974 he published in Nature his seminal paper on Lynch's Crater, demonstrating a radical vegetation change in northeast Australia around 38,000 years ago, at about the time when people were then thought to have first arrived on the continent (see Turney et al. 2006 for a subsequent redating of this vegetation change at Lynch's Crater, keeping in line also with subsequent redating of the first evidence of people in the landscape). This was also the year when the influential 'Sunda and Sahul' symposium was first planned (Allen et al. 1977), and the foundation year of the Australian Archaeological Association where, for the first time, researchers of Australian archaeology could assemble at an annual forum to share findings and discuss intellectual developments. This was a period of burgeoning interest in Australian Aboriginal archaeology and landscape history, where systematic connections were being forged between these two disciplines and interests (Aboriginal and landscape history). While discussions had by then already emerged on the role of people in shaping the environment (e.g. Jones 1968), especially through Rhys Jones' notion of 'firestick farming' (Jones 1969), and cause(s) of megafaunal extinctions had already long been debated since the 19th century (see Johnson 2007 for a review), what Peter brought to the equation were long environmental records and a conceptual shift signalling the necessary and obligatory incorporation of people into interpretations of landscapes, as managed and dynamic social spaces. From Peter's early works at Lynch's Crater, it was realised that it was simply not legitimate to interpret palaeoenvironments of the last $c .40,000$ years other than as peopled landscapes. This was not a matter of debating whether or not a particular archaeological or palaeontological assemblage showed evidence of human intervention, but rather a paradigm shift that newly saw palaeoecological sequences as only interpretable through consideration of human presence, given that people lived in the landscape and thus affected it. The question had become not so much whether or not people had a role to play in the evolution of the Australian landscape, nor whether they were palaeontologically or palynologically visible in that landscape, as a determination of the nature and scale of such interventions and their palaeoecological visibility.

From the outset Peter has been a key figure that led to a culture of research that closely enmeshed Australian archaeological with palaeoecological research during that period of the 


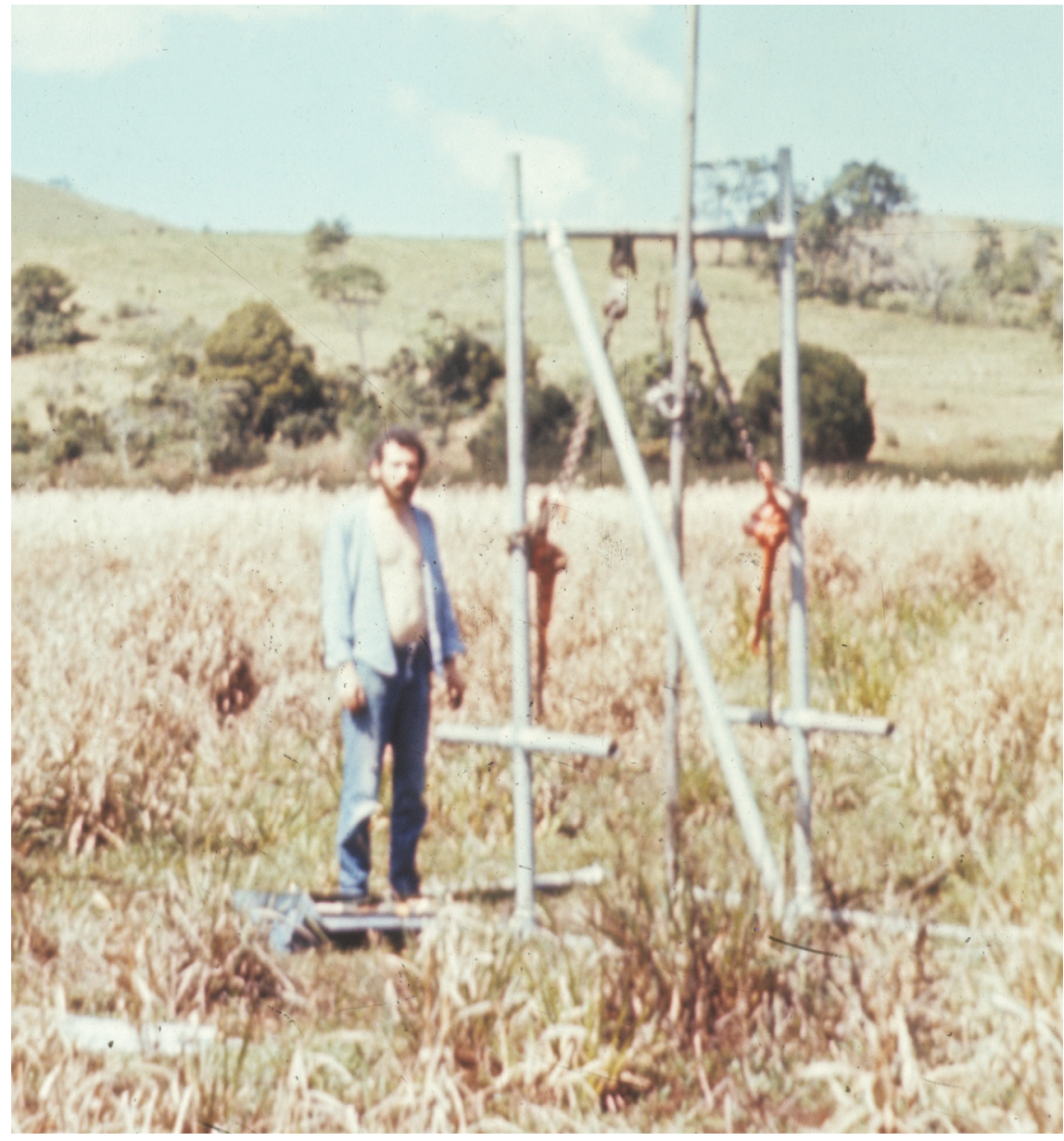

Figure 1. Coring at Lynch's Crater in 1971.

1970s when environmental understanding proved critical to archaeological paradigms. While today connections between culture and environment have largely been reframed to incorporate new nuances of 'dwelling', 'inhabitation' and the like (e.g. Thomas 2008), the kinds of research connections that Peter helped to frame between environmental and cultural sequences have resulted in strong research bonds between the disciplines of palaeoecology and archaeology in Australia and beyond.

\section{Peter Kershaw}

To properly understand, and appreciate, Peter's impact on the study of the Australian landscape we begin where he himself began. Peter grew up in Littleborough in the north of England where the industrial edge of Lancashire nosed up the valley into the peat-covered Pennine hills. He attended the local schools then went to the University of Wales at Aberystwyth where, as a student of geography, he first became aware of Quaternary pollen analysis. After acquiring an Honours degree, he moved to Durham University to do a Masters in ecology supervised by Judith Turner. Soon afterward he successfully applied for a research assistantship to Donald Walker, in the still infant laboratory at the ANU, to help extend the then dominating interest in Papua New Guinea to continental Australia.

Arriving with his wife Susan in the summer of 1967, Peter was given the task of observing the drilling in the Lake George basin by the Bureau of Mineral Resources and taking samples of any deposit there which might have contained preserved pollen. Such material as he was able to obtain, with much scepticism, in the field he found to be virtually barren in the laboratory; a very disappointing start. So a shift of emphasis was called for. 
Given the laboratory's existing tropical interests, it made sense to go north, specifically to the biogeographic boundary zone of the Atherton Tableland where, in 1962, Walker had established that pollen was plentifully preserved in a 'grab sample' of sediment from Lake Euramoo. Accordingly, the Walkers and the Kershaws entrained for Far North Queensland in June 1968 and set themselves up in half a house hired at the waterworks settlement of Tinaroo Falls where Peter voluntarily took on the additional evening duty of wheeling a two year-old Kate Walker around the streets to encourage her to sleep.

Fieldwork was not without its problems but, despite a raft that floated just below water level and what, in 2011, would be regarded as impossibly primitive coring equipment, a good sequence of samples was obtained and carried back to Canberra.

Months later, Peter presented Walker with an outline pollen diagram, undated, which undoubtedly showed sclerophyll woodland to have predated the existing rainforest of the Euramoo basin. Peter attributed this to a climatic change but Walker was not so sure, suggesting that it may have been a seral phenomenon immediately following the eruption by which the crater had been formed. The only way to solve the question was to sample more crater sediments of differing morphologies, and perhaps differing ages, in the region and date the vegetation change. It was also evident that Peter had a mind of his own in recognition of which he was awarded a scholarship to continue the work for a $\mathrm{PhD}$ and so threw off the shackles of assistantship. Thus was laid the foundation of a remarkable achievement in which Peter proved himself right (to Walker's delight) and established a basis from which he and others have made the Atherton Tableland the most concentrated source of palynological and related data in the tropical Quaternary world.

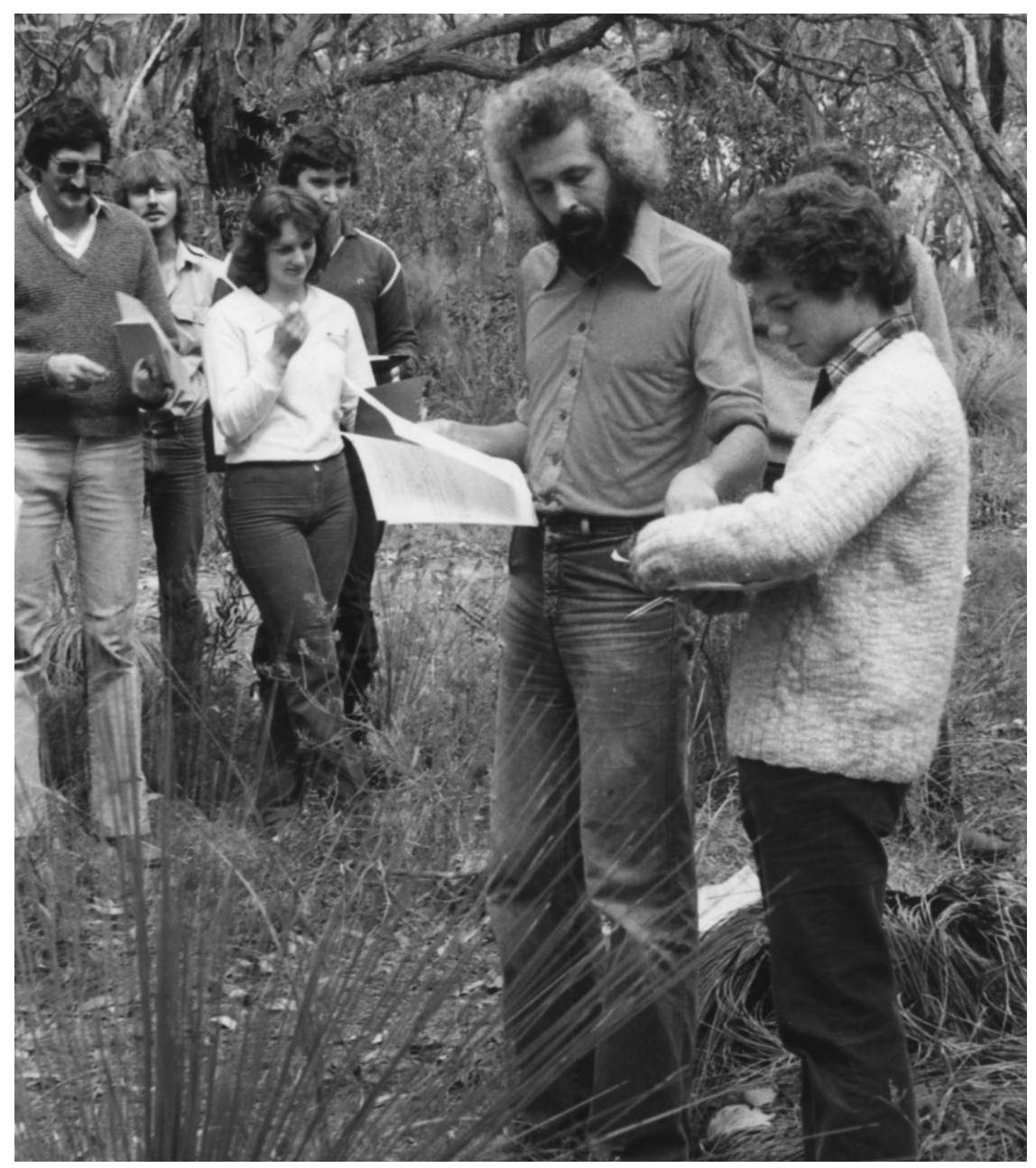

Figure 2. A biogeography field trip to Ironbark Basin, Angelsea, in the late 1970 s prior to the establishment of a post-1983 fire regeneration project that has continued with secondyear students to the present day. 
Peter subsequently moved from the ANU to the School of Geography and Environmental Science at Monash University, where he continues to foster environmental education and research (Figure 2). One of Peter's great strengths in teaching and research is to gather around him people with exceptional skills and dedication to the research tasks at hand. His long-term collaboration with his student and then colleague Merna McKenzie continues to produce invaluable insights into the nature of glacial cycles and tree-line fluctuations in southeast Australia. The arrival of Sander Van der Kaars, one of the first Logan Fellows at Monash University, ushered in a period of prolific pollen counting in the department, focussing on the potential for marine records from the west and north coasts of Australia to unlock our understanding of the influence of the monsoon on Australian landscapes. And Peter long promoted the incorporation of Indigenous archaeology in teaching and research of environmental science, a logical outcome of his early views of peopled landscapes; indeed it was his presence that caused Bruno David to come to the School of Geography and Environmental Science rather than the anthropology department in 1997 and thereby establish Monash University's first Indigenous archaeology programme (further developed a few years later by the arrival of Ian McNiven). These collaborations, and those with his many successful honours, post-graduate and post-doctoral fellows led to the School being regarded as the pre-eminant department for undergraduate and graduate training in biogeography and palaeoecology.

After some 44 years of academic research and teaching in Quaternary ecology and biogeography, Professor Peter Kershaw retired in October 2010. A meeting was held on 1st November 2010 at the Royal Society of Victoria in Melbourne, for a day honouring Peter's contributions to palaeoecology, biogeography and archaeology in the Australian region (Figure 3). The presentations listed below represent a snapshot of the legacy of Peter's endeavours, collaborations and inspiration that will no doubt resonate into the future of Quaternary research in our region. He is a valued colleague driven by his commitment to the discipline and graduate students, and in each of these areas he has achieved outstanding results:

- Matt McGlone, Keynote, "Separated at birth: physical, biological and social aspects of the trans-Tasman relationship"

- David Mercer \& Homer Le Grand, "Peter Kershaw's career at Monash"

- Martin Williams, "Did the $73 \mathrm{ka}$ Toba super-eruption have an enduring effect? Insights from archaeology, genetics, palynology, stable isotope geochemistry and climate models"

- Jim Bowler, "Fishing at the LGM: A day in the life of early boat people"

- Patrick De Deckker, "Multidisciplinary studies applied to core Fr10/95-GC17 offshore Northwest Cape, Western Australia"

- John Dodson, "Paradise Lost: tools and lessons on how human-kind shaped the world"

- Richard Cosgrove, "The Archaeologists Palynologist: the connection between archaeology and palaeoecology in Australia"

- Lesley Head, "Tomorrow is a long time: palaeoecology and contested landscapes in Sweden and Australia"

- Peter Gell, "Palaeoecology as a means of auditing wetland condition"

- Patrick Moss, "Holocene Landscape Change in the Humid Tropics of Northeastern Australia"

- John Tibby, "Palaeolimnological evidence for European impact in Australia"

- Kale Sniderman, "New insights from the fossil record into the history of Australia's sclerophyllous vegetation" 


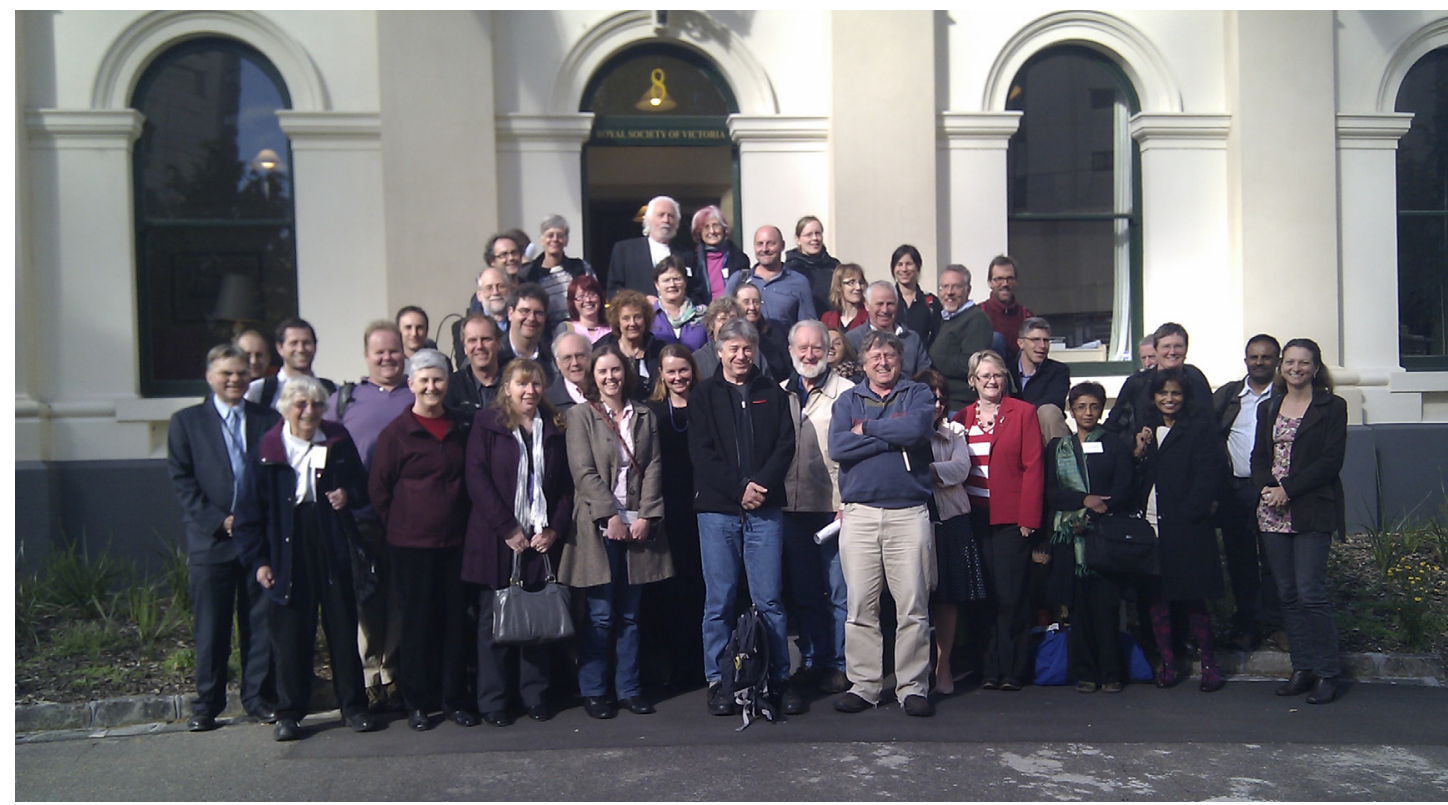

Figure 3. Attendants at the one-day meeting held at the Royal Society of Victoria in Melbourne, 1st November 2010, in honour of Peter Kershaw (centre, back row, whitest hair).

\section{Discussion}

By those who shared the laboratory with Peter at the ANU, he is perhaps best remembered for his goodwill, hard work, Dylan-style songs and his forcefully enunciated views on anything from pollen morphology to the dangers of religious bigotry. He was also the only member of those early years of ANU pollen research to count pollen while smoking a cigarette, particularly in the evenings when nobody else was working, as evidenced by the accumulation of ash around his microscope each following morning.

Perhaps fittingly, then, it was the application of charcoal analysis alongside pollen counts to explore the role of fire in vegetation change that showed an unprecedented change in fire regimes accompanying the arrival of people into Australia and that led to fundamental changes in the extent and composition of rainforests in the Atherton Tableland region. Such an approach was new and innovative at the time, being utilised in the Department of Biogeography and Geomorphology at the ANU to address questions of landscape change. Whether or not the timing and extent of these transformations reflected the wider tempo of change in the Australian landscape is yet to be fully resolved and is likely to occupy the lives of many Quaternary researchers for years to come.

Peter's concern with the Australian landscape as a peopled landscape meant, and means, that archaeologists need to consider landscape processes in the interpretation of excavated sequences, while geomorphologists and biogeographers need to consider people in their own interpretations of landscape processes. In this context and for the Australian region in particular, Peter's contribution to these disciplines have revolved around a number of major themes:

1. For Australia's long history, the visibility of people in the landscape through the effects of anthropogenic landscape burning.

2. As best shown at Lynch's Crater, but evident at numerous other sites also, the ability of individual pollen site sequences to implicate landscape histories. That is, the ability to transcend different spatial scales of interpretation, as evident by the ability of palynological research within individual sites to implicate whole landscape histories, an 
interpretative leap rarely legitimately achievable in purely archaeological research (Figure 4).

3. Peter was also the first person to securely date several glacial cycles in Australia and through the pollen records he showed that these cycles were different in their vegetation composition. This work came out of what was then seen as a pressing need to demonstrate synchronous orchestration of Australia's past climate with global climate signatures. He grasped the opportunity to open up the rich palynological fields of the western plains of Victoria, where maar deposits not unfamiliar to him from his earlier Atherton Tableland work yielded windows of opportunity to investigate the long Quaternary record of climate and vegetation change in southeast Australia.

4. The development of new and novel approaches to palaeoenvironmental reconstruction, particularly pioneering the use of bioclimatic profiles of extant taxa to generate quantitative palaeoclimatic estimates from pollen data (e.g. Kershaw and Nix 1988).

5. A preparedness to recognise that we do not know everything about the past, with present understandings sometimes turning to blind prejudice informed by the limitations of our data, meaning that we need to question conventional wisdom. Peter has thus been willing to play devil's advocate when new data hinted at the arrival of people in Australia 150,000-100,000 years ago, as evidenced by significant changes in pollen and carbonised particle frequencies in offshore sediments, northeast Australia (Kershaw et al.1993); and a subsequent preparedness to reverse his own views in light of subsequent findings (e.g. Moss and Kershaw 2000). While these new interpretations flew in the face of conventional wisdom - and were subsequently shown to be wrong - Peter was prepared to shake the discipline(s) in light of evidence that required explanation.

6. Expanding our understanding of the deep-time biogeography of Australian rainforests and sclerophyll plants, most notably the Araucariaceae, an iconic Gondwanan family (Kershaw and Wagstaff 2001).

7. The encouragement of cross-disciplinary research and use of multi-proxy evidence to strengthen the reliability and interpretability of research findings.

These themes have each significantly contributed to how we now come to read, and understand, the Australian landscape as historically created from some 50,000 years of Aboriginal engagements with their surroundings. In this spirit of investigation, where understanding landscape history requires a joining rather than separation of parts (e.g. plants vs sediments vs people), in this volume we present a set of papers by scientists who have each been directly influenced by Peter's work. The case studies presented each consider the landscape as one that has developed with people in its midst. These are not prefigured landscapes as stages for people to subsequently act upon, but rather engaged landscapes at their very core: landscapes that are defined by such engagements. In this sense a peopled landscape is one that would not exist in that form without those who gave it its particular characteristics. One of our roles, as archaeologists, geomorphologists, palaeoecologists and biogeographers, is to determine the nature of those historical engagements that enable us to define how in history people have come to influence and shape the world in which we live today. This is the ongoing legacy of Peter Kershaw's ongoing contributions to the study of landscape history (Figure 5). 

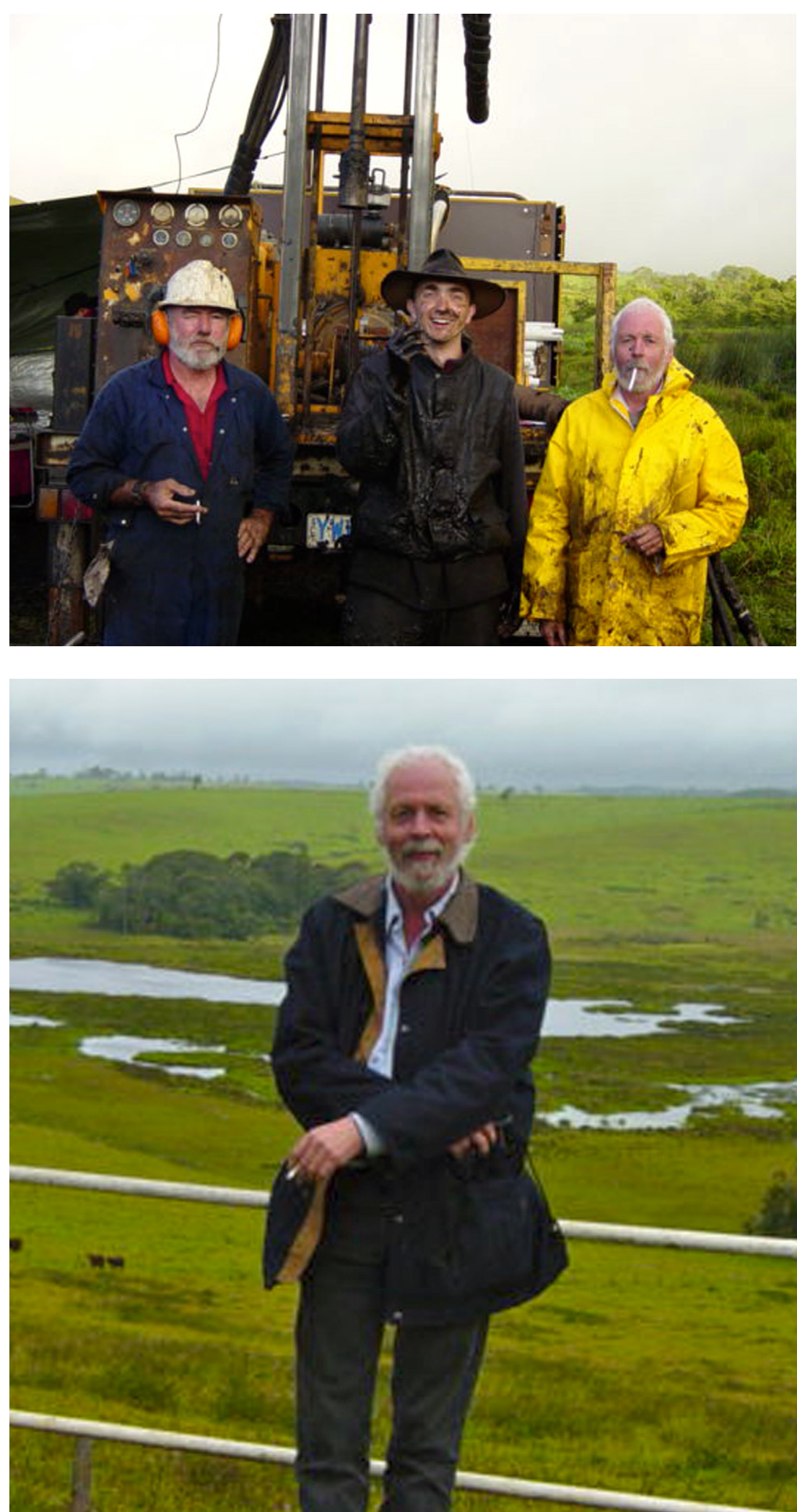

Figure 4. Peter Kershaw (right) celebrating another successful coring expedition at Lynch's Crater in 2004 with Damien Kelleher (left) and Chris Turney (middle).

Figure 5. Peter Kershaw at the Bromfield Swamp lookout in 2004.

\section{References}

Allen, J., Golson, J. and Jones R. (eds) 1977. Sunda and Sahul: Prehistoric Studies in Southeast Asia, Melanesia and Australia. Academic Press, London.

Hale,P. and Lamb, D. (eds) 1997. Conservation Outside Nature Reserves. Centre for Conservation 
Biology, University of Queensland, Brisbane.

Johnson, C. 2007. Australia's Mammal Extinctions: A 50,000-Year History. Cambridge University Press, Cambridge.

Jones, R. 1968. The geographical background to the arrival of man in Australia and Tasmania. Archaeology and Physical Anthropology in Oceania 3:186-215.

Jones, R. 1969. Fire-stick Farming. Australian Natural History 16:224-228.

Kershaw, A.P. 1973. Late quaternary vegetation of the Atherton Tableland, north-east Queensland, Australia. PhD Thesis, Australian National University, Canberra.

Kershaw, A.P. 1974. A long continuous pollen sequence from northeastern Australia. Nature 251:222-223.

Kershaw, A.P., McKenzie, G.M. and McMinn, A. 1993. A Quaternary vegetation history of northeast Queensland from pollen analysis of ODP Site 820. Proceedings of the Ocean Drilling Program 133:107-114.

Kershaw, A.P and Nix, H.A. 1988. Quantitative palaeoclimatic estimates from pollen data using bioclimatic profiles of extant taxa. Journal of Biogeography 15:589-602.

Kershaw, A.P. and Wagstaff, B.E. 2001. The southern conifer family Araucariaceae: history, status, and value for palaeoenvironmental reconstruction. Annual Review of Ecology and Systematics 32:397-414.

Moss,P.T. and Kershaw, A.P. 2000. The last glacial cycle from the humid tropics of northeastern Australia: Comparison of a terrestrial and a marine record.Palaeogeography, Palaeoclimatology, Palaeoecology 155(1-2):155-176.

Thomas, J. 2008. Archaeology, landscape, and dwelling. In: David, B. and Thomas, J. (eds), Handbook of Landscape Archaeology, pp. 300-306. Left Coast Press, Walnut Creek.

Turney, C.S.M., Kershaw, A.P., James, S., Branch, N., Cowley, J., Fifield, L.K., Jacobsen, G. and Moss, P. 2006. Geochemical changes recorded in Lynch's Crater, northeastern Australia, over the past 50 ka. Palaeogeography, Palaeoclimatology, Palaeoecology 233:187-203. 


\section{Publications - A. Peter Kershaw, 1970-2011}

Books and special jounal issues

Kershaw, A.P., Haberle, S.G, Turney, C.S.M. and Bretherton, S.C. (eds) 2007. Environmental history of the humid tropics region of north-east Australia. Special issue Palaeogeography, Palaeoclimatology, Palaeoecology 251 (1):1-173.

Kershaw, P., Chappellaz, J., Newman, L. and Kiefer, T. (eds) 2007. Past Climate Dynamics: $A$ Southern Perspective. Past Global Changes (PAGES) News 15(2):1-27.

Turney, C.S.M., Kershaw, A.P. and Lynch, A. (eds) 2006. Integrating High Resolution Past Climate Records for Future Prediction in the Australasian Region. Special issue Journal of Quaternary Science 21 (7):679-801.

Bottjer,D.J.,Correge,T., Kershaw,A.P. and Surlyk,F.(eds) 2006. Exploring Life and Environments Through Time: Celebrating the 40th Anniversary of Palaeo-3. Special issue Palaeogeography, Palaeoclimatology, Palaeoecology 232 (2-4):97-458.

Kershaw, A.P. and Orr, M.L. (eds) 2004. Environmental History of the Newer Volcanic Province of Victoria. Thematic issue, Proceedings of the Royal Society of Victoria 116 (1):1-182.

Kershaw, A.P., David, B., Tapper, N.J., Penny, D. and Brown, J. (eds) 2002. Bridging Wallace's Line: The Environmental and Cultural History and Dynamics of the Southeast Asian-Australian Region. Catena Verlag., Reiskirchen, Germany, 360 pp.

Dam, R.A.C., van der Kaars, S. and Kershaw, A.P.(eds) 2001. Quaternary Environmental Change in the Indonesian Region. Special issue, Palaeogeography, Palaeoclimatology, Palaeoecology 171 (3-4):421pp.

Kershaw, A.P. and Whitlock, C. (eds) 2000. Last Glacial-Interglacial Cycle: Patterns and Causes of Change. Special issue, Palaeogeography, Palaeoclimatology, Palaeoecology 155 (1-2):1-209.

Partridge, T., Kershaw, A.P. and Iriondo, M. (eds) 1999. Palaeoclimates of the Southern Hemisphere During the Last 200,000 Years:Data, Models and Regional Syntheses. Special issue, Quaternary International 58/58:1-235.

Kershaw, A.P., Pittock, B. and Simmonds, I. (eds) 1998. Climate Change in the Australian Region: Quantifying the Past to Understand the Future. Special Issue, Palaeoclimates: Data and Modelling 3:1-238.

Williams, M.A.J., Dunkerley, D.L., De Deckker, P., Kershaw, A.P. and Chappell, J. 1998. Quaternary Environments. 2nd Edition. Edward Arnold, 329pp.

Williams, M.A.J., Dunkerley, D.L., De Deckker, P., Kershaw, A.P. and Stokes, T. 1997. Quaternary Environments. Chinese Edition, 329pp.

Williams, M.A.J., Dunkerley, D.L., De Deckker, P., Kershaw, A.P. and Stokes, T. 1993. Quaternary Environments. Edward Arnold, 329pp.

Williams, M.A.J., De Deckker, P. and Kershaw, A.P. 1991. The Cainozoic in Australia: A Reappraisal of the Evidence. Geological Society of Australia, Special Publication No. 18, 346 pp.

Werren, G.L. and Kershaw, A.P.(eds) 1991. The Rainforest Legacy:Australian National Rainforests Study Vol. 2 - Flora and Fauna of the Rainforests. Special Australian Heritage Publication Series No. 7 (2), Australian Heritage Commission, 414 pp.

Werren, G.L. and Kershaw, A.P. (eds) 1991. The Rainforest Legacy: Australian National Rainforests Study Vol. 3 - Rainforest History, Dynamics and Management. Special Australian Heritage Publication Series No. 7 (3), Australian Heritage Commission, 309 pp.

Werren, G.L. and Kershaw,A.P.(eds) 1987. The Rainforest Legacy:Australian National Rainforests Study Vol 1 - The Nature, Distribution and Status of Rainforest Types. Special Australian Heritage Publication Series No. 7 (1), Australian Heritage Commission, 344 pp.

Luly, J., Sluiter, I.R. and Kershaw, A.P. 1980. Pollen studies of Tertiary brown coals: preliminary analyses of lithotypes within the Latrobe Valley, Victoria. Monash Publications in Geography No. 23, 78pp. 
Chapters in books

Kershaw, A.P. and van der Kaars, S. In Metcalfe, S.E. and Nash, D.J. (eds) (in press) Tropical Quaternary climates in Australia and the south-west Pacific. Quaternary Environmental Change in the Tropics. Blackwell Scientific Publishers, Oxford.

Porch, N. and Kershaw, A.P. 2010. Comparative AMS 14C dating of plant macrofossils, beetles and pollen preparations from two late Pleistocene sites in southeastern Australia. In: Haberle, S.G., Stevenson, J. and Prebble, M. (eds), Altered Ecologies: Fire, Climate and Human Influence on Terrestrial Landscapes, Terra Australis 32, pp. 395-403. ANU E-Press, Canberra, Australia.

Kershaw, A.P., G.M. McKenzie, J. Brown, R.G. Roberts, and S. van der Kaars 2010. Beneath the peat: A refined pollen record from an interstadial at Caledonia Fen, highland eastern Victoria, Australia. In: Haberle, S.G., Stevenson, J. and Prebble, M. (eds), Altered Ecologies: Fire, Climate and Human Influence on Terrestrial Landscapes, Terra Australis 32, pp. 33-48. ANU E-Press, Canberra, Australia.

Rowe, C. and Kershaw, A.P. 2008. Microbotanical remains in landscape archaeology. In: David, B. (ed) Handbook of Landscape Archaeology, pp. 430-441. Left Coast Press, California.

Kershaw, A.P. and van der Kaars, S. 2007. Pollen records, Late Pleistocene, Australia and New Zealand. In: Elias, S.A. (ed), Encyclopedia of Quaternary Science, Vol. 4, pp. 2613-2622. Elsevier, Amsterdam.

Kershaw, A.P., van der Kaars, S. and Flenley, J.F. 2007. The Quaternary history of far eastern rainforests. In: Bush, M.B. and Flenley, J.F. (eds), Tropical Rainforest Responses to Climate Change, pp. 77-115. Springer-Praxis, Berlin.

Tibby, J., Kershaw, A.P., Builth, H., Philibert, A. and White, C. 2006. Environmental change and variability in south-western Victoria: changing constraints and opportunities for occupation and land use. In: David, B., Bryson, B. and McNiven, I. (eds), The Social Archaeology of Indigenous Societies, pp. 254-269. Aboriginal Studies Press, Canberra.

Kershaw, A.P., Moss, P.T. and Wild, R. 2005. Patterns and causes of vegetation change in the Australian Wet Tropics region over the last 10 million years. In: Bermingham, E., Dick, C. and Moritz, C. (eds), Tropical Rainforests: Past Present and Future, pp. 374-400. The University of Chicago Press, Chicago.

Kershaw, A.P., van der Kaars, S., Moss, P.T. and Wang, X. 2002. Palynological evidence for environmental change in the Indonesian-northern Australian region over the last 140,000 to 300,000 years. In: Kershaw, A.P., David, B., Tapper, N.J., Penny, D. and Brown, J. (eds), Bridging Wallace's Line: The Environmental and Cultural History and Dynamics of the Southeast Asian - Australian Region, pp. 97-118. Catena Verlag, Reiskirchen, Germany.

David, B., Kershaw, A.P. and Tapper, N. 2002. Bridging Wallace's Line: Bringing home the Antipodes. In: Kershaw, A.P., David, B., Tapper, N.J.,Penny, D. and Brown, J. (eds), Bridging Wallace's Line: The Environmental and Cultural History and Dynamics of the Southeast Asian - Australian Region, pp. 1-4. Catena Verlag, Reiskirchen, Germany.

Kershaw, A.P., Clark, J.S. and Gill, A.M. 2002. A history of fire in Australia. In: Bradstock, R., Williams, J. and Gill, A.M. (eds), Flammable Australia: the Fire Regimes and Biodiversity of a Continent, pp. 3-25. Cambridge University Press, Cambridge.

Clark, J.S., Gill, A.M. and Kershaw, A.P. 2002. Spatial variability in fire regimes: its effects on recent and past vegetation. In: Bradstock, R., Williams, J. and Gill, A.M. (eds), Flammable Australia: the Fire Regimes and Biodiversity of a Continent, pp. 125-141. Cambridge University Press, Cambridge.

Kershaw, A.P., Penny, D., van der Kaars, S., Anshari, G. and Thamotherampillai, A. 2001. Evidence for vegetation and climate in lowland southeast Asia at the Last Glacial Maximum. In: Melcalfe, I., Smith, J.M.B., Morwood, M. and Davidson, I. (eds), Floral and 
Faunal Migrations and Evolution in Southeast Asia-Australasia, pp. 227-236. A.A. Balkema, Lisse.

Moss, P.T. and Kershaw, A.P. 1999. Evidence from marine ODP Site 820 of fire/vegetation/ climate patterns in the humid tropics of Australia over the last 250,000 years. Proceedings, Australian Bushfire Conference: Bushfire 99, pp. 269-279. Charles Sturt University, Albury, NSW.

Kershaw, A.P., Bush, M., Hope, G.S., Weiss, K., Goldammer, J.G. and Sanford Jr., R. 1997. The contribution of humans to past biomass burning in the tropics. In: Clark, J., Cachier, H., Goldammer, J.G. and Stocks, B. (eds), Sediment Records of Biomass Burning and Global Change, pp. 413-442. Springer, Berlin.

Kershaw, A.P. 1997. Environments of mainland southeastern Australia at the climatic extremes of the last glacial cycle: evidence from pollen. In: Mecco, J. and Petit-Maire, N. (eds), Climates of the Past, pp. 115-122. Servicio de Publicaciones, Universidad de Las Palmas de Gran Canaria: Canary Islands.

Kershaw, A.P. and Bohte, A. 1997. The impact of prehistoric fires on tropical peatland forests. In: Rieley, J.O. and Page, S.E. (eds), Biodiversity and Sustainability of Tropical Peatlands, pp. 73-80. Samara Press, Tresaith, Cardigan.

Kershaw, A.P., Reid, M. and Bulman, D. 1997. The nature and development of peatlands in Victoria. In: Rieley, J.O. and Page, S.E. (eds), Biodiversity and Sustainability of Tropical Peatlands, pp. 81-91. Samara Press, Tresaith, Cardigan.

Kershaw, A.P. 1997. A history of biomass burning in the tropics: relative contributions of climate and people. In: Sirinanda, K.U. (ed), Climate and Life in the Asia-Pacific, pp. 130142. Department of Geography, Universiti Brunei Darussalam, Brunei.

Allen, J. and Kershaw, A.P. 1996. The Pleistocene-Holocene transition in Greater Australia. In: Straus, L.G., Eriksen, B.V., Erlandson, J.M. and Yesner, D.R. (eds), Humans at the End of the Ice Age. The Archaeology of the Pleistocene-Holocene Transition, pp.171-199. Plenum Press, New York.

Balme, B.E., Kershaw, A.P. and Webb, J. 1995. Floras of Australian coal measures. In: Ward, C.R., Harrington, H.J., Mallett, C.W. and Beeston, J.W. (eds), Geology of Australian Coalfields, pp. 41-62. Geological Society of Australia, Sydney.

Kershaw, A.P. 1995. Pollen representation of peatland vegetation, Victoria, Australia. In: Dixon, G. and Aitken, D. (eds), Institute of Australian Geographers: Conference Proceedings, 1993, Monash Publications in Geography No. 45, pp. 162-167. Dept. of Geography and Environmental Science, Monash University, Melbourne.

Kershaw, A.P. and McGlone, M. 1995. The Quaternary history of the southern conifers. In: Enright, N. and Hill, R.S. (eds), The Ecology of the Southern Conifers, pp. 30-63. Melbourne University Press, Melbourne.

Dodson, J. and Kershaw, A.P. 1994. Evolution and history of Mediterranean vegetation types in Australia. In: Kalin Arroyo, M.T., Zedler, P.H. and Fox, M.D. (eds), Ecology and Biogeography of Mediterranean Ecosystems in Chile, Califormia and Australia, pp. 21-40, Springer-Verlag, New York.

Kershaw, A.P. 1994. Historical development of the vegetation. In: Bambrick, S. (ed) The Cambridge Encyclopedia of Australia, pp. 22-24. Cambridge University Press, Cambridge.

Ladiges, P., Kershaw, A.P. and Rich, P. 1994. Australian Environments and Biota. In: Knox, B., Ladiges, P. and Evans, B. (eds) Biology, pp. 904-933. McGraw-Hill, Sydney.

Kershaw, A.P., Martin, H.A. and McEwen Mason,J. 1994. The Neogene - a period of transition. In: Hill, R. (ed), Australian Vegetation History. Cretaceous to Present, pp. 435-462, Cambridge University Press, Cambridge.

McGlone, M., Kershaw, A.P. and Markgraf, V. 1992. El Nino-Southern Oscillation and 
climatic variability in Australasian and South American palaeoenvironmental records. In: Diaz, H.F. and Markgraf, V. (eds), El Nino: Historical and Palaeoclimatic Aspects of the Southern Oscillation, pp. 435-462. Cambridge, University Press Cambridge.

Kershaw, A.P. 1992. The development of rain-forest-savanna boundaries in tropical Australia. In: Furley, P.A., Proctor, J. and Ratter, J.A. (eds), Nature and Dynamics of Forest-Savanna boundaries, pp. 255-271. Chapman Hall, London.

Kershaw, A.P. 1992. The development and history of temperate zone rainforests in Australia. In: Gell, P. and Mercer, D. (eds), Victoria's Rainforests: Perspectives on Definition, Classification and Management. Monash Publications in Geography No. 41, pp. 107-115. Dept. of Geography and Environmental Science, Monash University, Melbourne.

Kershaw, A.P. 1992. Past vegetational and climatic change in Victoria: What can it show? In: Pittock, J. (ed), Victoria's Flora and Fauna: Can it Survive the Greenhouse Effect?, pp. 13-15. Victorian National Parks Association, Melbourne.

Hiscock, P. and Kershaw, A.P. 1992. Palaeoenvironments and prehistory of Australia's tropical top end.In J.R. Dodson (ed.) The Naive Lands: Human/Environment Interactions in Australia and Oceania, pp. 43-75. Longman Cheshire, Melbourne.

Kershaw, A.P., Sluiter, I.R., McEwen Mason, J., Wagstaff, B.E. and Whitelaw, M. 1991. The history of rainforest in Australia: evidence from pollen. In: Werren, G.L. and Kershaw, A.P. (eds), The Rainforest Legacy: Australian National Rainforests Study Vol. 3 - Rainforest History, Dynamics and Management, pp. 1-15. Special Australian Heritage Publication Series, Canberra.

Kershaw, A.P., Baird, J., D’Costa, D., Edney, P., Peterson, J.A. and Strickland, K.M. 1991. A comparison of long Quaternary pollen records from the Atherton and Western Plains volcanic provinces. In: Williams, M.A.J., De Deckker, P. and Kershaw, A.P. (eds), The Cainozoic in Australia: a re-appraisal of the evidence, pp. 288-301. Geological Society of Australia: Sydney.

Kershaw, A.P. and Strickland, K.M. 1990. The development of alpine vegetation on the Australian mainland.In: Good, R.(ed) Proceedings of the First Fenner Conference: the Scientific Significance of the Australian Alps, pp. 113-126. Australian Academy of Science, Canberra

Kershaw, A.P. and Gell, P.A. 1990. Quaternary vegetation and the future of the forests. In: Bishop, P. (ed), Lessons for human survival: nature's record from the Quaternary, pp. 11-20. Geological Society of Australia Symposium Proceedings 1, Sydney.

Kershaw, A.P. and Nix, H.A. 1989. Quantitative palaeoclimatic estimates from pollen data. In: Donnelly, T.H. and Wasson, R. (eds), CLIMANZ 3: Proceedings of Symposium, Melbourne 1987, pp. 78-85. Division of Water Resources, CSIRO, Canberra.

Kershaw, A.P. and Whiffin, T. 1989. Australia. In: Campbell, D.G. and Hammond, H.D. (eds), Floristic Inventory of Tropical Countries: the Status of Plant Systematics, Collections and Vegetation, Plus Recommendations for the Future, pp. 149-165. The New York Botanical Garden, New York.

Kershaw, A.P. 1988. Australasia. In: Huntley, B. and Webb 11l, T. (eds), Vegetation History, pp. 237-306. Kluwer Academic Publishers, Dordrecht.

Williams, M.A.J., De Deckker, P. and Kershaw, A.P. 1988. Past environmental analogues. In: Pearman, G. (ed) Greenhouse: planning for climate change, pp. 473-488. CSIRO, Melbourne.

Truswell, E.M., Kershaw, A.P. and Sluiter, I.R. 1987. The Australian/Malaysian connection: evidence from the palaeobotanical record. In: Whitmore, T.C. (ed) Biogeographic Evolution of the Malay Archipeligo, pp. 32-49. Clarendon Press, Oxford.

Raby, G., van Djik, M. and Kershaw, A.P. 1987. Climate. In: Vampley, W. (ed), Australians: Historical Statistics, pp. 62-68. Fairfax, Syme and Weldon, Broadway, NSW. 
Kershaw, A.P. 1987 A comparative vegetation history of southeastern Australia and New Zealand. In: Conacher, A. (ed), Readings in Australian Geography, pp. 433-445. Institute of Australian Geographers (W.A. Branch) and Department of Geography, University of Western Australia, Perth.

Kershaw, A.P., McEwen Mason, J.R., McKenzie, G.M., Strickland, K.M. and Wagstaff, B.E. 1986. Aspects of the development of cold-adapted flora and fauna in the Cenozoic of southeastern mainland Australia.In: Barlow, B.A.(ed), Flora and Fauna of Alpine Australasia, ages and origins, pp. 147-160. CSIRO, Canberra.

Kershaw, A.P. 1984 Some applications of studies on vegetation and fire history to forest management. In: Ealey, E.H.M. (ed), Fighting fire with fire: A symposium on fuel reduction burning in forests, pp. 55-69. Graduate School of Environmental Science, Monash University, Melbourne.

Kershaw, A.P., Sluiter, I.R., Dawson, J., Wagstaff, B.E. and Whitelaw, M. 1984. The history of rainforest in Australia. In: Werren, G.L. and Kershaw, A.P. (eds), The Rainforest Legacy: Australian National Rainforests Study Vol 1 - The Nature, Distribution and Status of Rainforest Types, Special Australian Heritage Publication Series No. 7 (1), pp. 462-77. Australian Heritage Commission, Canberra.

Kershaw, A.P. 1984. Late Cenozoic plant extinctions in Australia. In: Martin, P.S. and Klein, R.G. (eds), Quaternary Extinctions, a Prehistoric Revolution, pp. 691-707. University of Arizona Press, Tucson.

Kershaw, A.P. 1984. Review of Quaternary studies in Australia - plant and invertebrate palaeoecology. In: Quaternary Studies in Australia: future directions, pp. 67-82. Bureau of Mineral Resources, Geology and Geophysics Record 1984/14, Canberra.

Kershaw, A.P. 1983. The vegetation record from northeastern Australia 40,000 - 3000 B.P.. In: Chappell, J.M.A. and Grindrod, A. (eds), CLIMANZ: Quaternary Climatic History of Australia, pp. 25, 37, 61-2, 79-80, 100-1. Dept. of Biogeography and Geomorphology, Australian National University, Canberra.

Kershaw, A.P., Southern, W., Williams, J.M. and Joyce, L.J. 1983. The vegetation record from the southeastern highlands of mainland Australia 40,000 - 3000 B.P. In: Chappell, J.M.A. and Grindrod, A. (eds), CLIMANZ: Quaternary Climatic History of Australia, pp. 16, 37-8, 62, 80-1,101, Dept. of Biogeography and Geomorphology, Australian National University, Canberra.

Kershaw, A.P. 1982. Holocene Palaeoecology. In: Thom, B.G. and Wasson, R. (eds), Holocene Research in Australia 1978-1982, pp. 78-110. Occasional Paper No. 33, Dept. of Geography, Royal Military College, Duntroon, Canberra.

Kershaw, A.P. 1981. Quaternary vegetation and environments. In: Keast, A. (ed), Ecological Biogeography in Australia, pp. 83-101. Dr. W. Junk, La Hague.

Singh, G., Kershaw, A.P. and Clark, R. 1981. Quaternary vegetation and fire history in Australia. In: Gill, A.M., Groves, R.A. and Noble, I.R. (eds), Fire and Australian Biota, pp. 23-54. Australian Academy of Science, Canberra.

Kershaw, A.P. 1980. Long term changes in north-east Queensland rainforest. In: Wright, J., Mitchell, N. and Watling, P. (eds), Reef, Rainforest, Mangrove, Man, pp. 32-38. Wildlife Preservation Society of Queensland, Brisbane.

Kershaw, A.P. 1980. Evidence for vegetation and climatic change during the Quaternary. In: Henderson, R.A. and Stephenson, P.J. (eds), The Geology and Geophysics of northestern Australia, pp. 398-402. Geological Society of Australia (Q1d. Div.), Brisbane.

Kershaw, A.P. 1975. Late Quaternary vegetation and climate in north-eastern Australia. In: Suggate, R.P. and Creswell, M.M. (eds), Quaternary Studies, pp. 181-187. Royal Society of New Zealand, Wellington. 
Kershaw, A.P. 1973. The numerical analysis of modern pollen spectra from north-east Queensland rainforests. In: Glover, J.E. and Playford, G. (eds), Mesozoic and Cainozoic Palynology: Essays in Honour of Isabell Cookson, pp. 191-9. Special publication, Geological Society of Australia, No. 4, Sydney.

\section{Journal articles}

Mooney, S.D., Harrison, S.P., Bartlein, P.J., Daniau, A.-L., Stevenson, J., Brownlie, K.C., Buckman, S., Cupper, M., Luly, J., Black, M., Colhoun, E., D‘Costa, D., Dodson, J., Haberle, S.G., Hope, G.S., Kershaw, P., Kenyon, C., McKenzie, M. and Williams, N. 2011. Late Quaternary fire regimes of Australasia. Quaternary Science Reviews 30:28-46.

Haberle, S.G., Rule, S., Roberts, P., Heijnis, H., Jacobsen, G., Turney, C., Cosgrove, R., Ferrier, A., Moss, P., Mooney, S., and Kershaw, P. 2010. Paleofire in the wet tropics of northeast Queensland, Australia. PAGES Nerws 18(2):78-80.

Walker, M., Johnsen, S., Rasmussen, S.O., Steffensen, J.-P., Popp, T., Gibbard, P., Hoek, W., Lowe, J., Andrews, J., Björck, S., Cwynar, L., Hughen, K., Kershaw, P., Kromer, B., Litt, T., Lowe, D.L., Nakagawa, T., Newnham, R. and Schwander, J. 2009. Formal definition and dating of the GSSP (Global Stratotype Section and Point) for the base of the Holocene using the Greenland NGRIP ice core, and selected auxiliary records. Journal of Quaternary Science 24:3-17.

Williams, M., Cook, E., van der Kaars, S., Barrows, T., Shulmeister, J. and Kershaw, P. 2009. Glacial and deglacial climatic patterns in Australia and surrounding regions from 35000 to 10000 years ago reconstructed from terrestrial and near-shore proxy data. Quaternary Science Reviews 28:2398-2419.

Goodall, R.A., David, B., Kershaw, P. and Fredricks, P.M. 2009. Prehistoric hand stensils at fern Cave, North Queensland, Australia: environmental and chronological implications of Raman spectroscopy and FT-IR imaging results. Journal of Archaeological Science 36:26172624.

Coulter, S.E., Turney, C.S.M., Kershaw, P. and Rule, S. 2009. The characterisation and significance of a MIS 5a distal tephra on mainland Australia. Quaternary Science Reviews 28:1825-1830.

Walker, M., Johnsen, S., Rasmussen, S.O., Steffensen, J.-P., Popp, T., Gibbard, P., Hoek, W., Lowe, J., Andrews, J., Björck, S., Cwynar, L., Hughen, K., Kershaw, P., Kromer, B., Litt, T., Lowe, D.L., Nakagawa, T., Newnham, R. and Schwander, J. 2008. The Global Stratotype Section and Point (GSSP) for the base of the Holocene Series/Epoch (Quaternary System/ Period) in the NGRIP ice core. Episodes 31:264-267.

Builth, H., Kershaw, A.P., White, C., Roach, A., Hartney, L., McKenzie, M., Lewis, T. and Jacobsen, G. 2008. Environmental and cultural change on the Mt Eccles lava flow landscapes of south-west Victoria, Australia. The Holocene 18:421-432.

Brooks, B.W., Bowman, D.M.J.S., Burney, D.A., Flannery, T.F., Gagan, M.K., Gillespie, R., Johnson, C.N., Kershaw, A.P., Magee, J.W., Martin, P.S., Miller, G.H., Peiser, B. and Roberts, R.G. 2007. Would the Australian megafauna have become extinct if people had never colonized the continent? Comments on 'A review of the evidence for a human role in the extinction of Australian megafauna and an alternative explanation' by S. Wroe and J. Field. Quaternary Science Reviews 26:560-564.

Lynch, A.H., Beringer, J., Kershaw, P., Marshall, A., Mooney, S., Tapper, N., Turney, C. and van Der Kaars, S. 2007. Using the paleorecord to evaluate climate and fire interactions in Australia. Annual Review of Earth and Planetary Sciences 35:215-239.

Moss, P.T. and Kershaw, A.P. 2007. A late Quaternary marine palynological record (Oxygen isotope stages 1-7) for the Humid Tropics of northeastern Australia based on ODP Site 
820). Palaeogeography, Palaeoclimatology, Palaeoecology 251:4-22.

Kershaw, A.P., Bretherton, S.C. and van der Kaars, S. 2007. A complete pollen record of the last 230 ka from Lynch's Crater, northeastern Australia. Palaeogeography, Palaeoclimatology, Palaeoecology 151:23-45.

Kershaw, A.P., McKenzie, G.M., Porch, N., Roberts, R.G., Brown, J., Heijnis, H., Orr, L.M., Jacobsen, G. and Newall, P.R. 2007. A high resolution record of vegetation and climate through the last glacial cycle from Caledonia Fen, south-eastern highlands of Australia. Journal of Quaternary Science 22:481-500.

Reid, M.A., Sayer, C.D., Kershaw, A.P. and Heijnis, H. 2007. Palaeolimnological evidence for submerged plant loss in a floodplain lake associated with accelerated catchment soil erosion (Murray River, Australia). Journal of Paleolimnology 38:191-208.

Sniderman, J.M.K., Pillans, B., O’Sullivan, P.B. and Kershaw, A.P.2007. Climate and vegetation in southeastern Australia respond to Southern Hemisphere insolation forcing in the late Pliocene - early Pleistocene. Geology 35:41-44.

Turney, C.S.M., Haberle, S.G., Fink, D., Kershaw, A.P., Barbetti, M., Barrows, T.T., Black, M., Cohen, T.J., Correge, T., Hesse, P.P., Qua, Q. Johnston, R., Morgan, V., Moss, P., Nanson, G., Van Ommen, T., Rule, S., Williams, N.J., Zhao, J-X., D’Costa, D., Feng, Y-X., Gagan, M., Mooney, S. and Xia, Q. 2006. Integration of ice-core, marine and terrestrial records for the Australian Last Glacial Maximum and Termination: a contribution from the $\mathrm{OZ}$ INTIMATE group. Journal of Quaternary Science 21:751-761.

Kershaw, P., van der Kaars, S., Moss, P., Opdyke, B., Guichard, F., Rule, S. and Turney, C. 2006. Environmental change and the arrival of people in the Australian region. Before Farming [Online] http://www.waspress.co.uk/journals/beforefarming/journal_20061/ 2006/1 article 2.

Turney, C.S.M., Kershaw, A.P., James, S., Branch, N., Cowley, J., Fifield, L.K., Jacobsen, G. and Moss, P. 2006. Geochemical changes recorded in Lynch's Crater, northeastern Australia, over the past 50 ka. Palaeogeography, Palaeoclimatology, Palaeoecology 233:187-203.

Turney C.S.M., Kershaw, A.P., Lowe, J.J., van der Kaars, S., Johnston, R., Rule, S., Moss, P., Radke, L., Tibby, J., McGlone, M.S., Wilmshurst, J.M., Vandergoes, M.J., Fitzsimons, S.J., Bryant, C., Branch, N.P., Jacobsen, G. and Fifield, L.K. 2006. Climatic variability in the southwest Pacific during the Last Termination (20-10ka BP). Quaternary Science Reviews 25:886-903.

Moss, P.T., Kershaw, A.P. and Grindrod, J. 2005. Pollen transport and deposition in riverine and marine environments within the humid tropics of northeastern Australia. Review of Palaeobotany and Palynology 134:55-69.

Barry, M.J., Tibby, J., Tsitsilas, A., Mason, B., Kershaw, A.P. and Heijnis, H. 2005. A long term lake salinity record and its relationships to Daphnia populations. Archiv. fur Hydrobiologie 163:1-23.

Leahy, P.G., Tibby, J., Kershaw, A.P., Heijnis, H. and Kershaw, J.S. 2005. A palaeolimnological reconstruction of the impact of European settlement on the Yarra River floodplain, Victoria, Australia. River research and Management 21:131-149.

Wang, P., Clemens, S., Beaufort, L., Bracannot, P., Ganssen, G., Jian, Z., Kershaw, A.P. and Sarnthein, M. 2005. Evolution and variability of the Asian monsoon system: state of the art and outstanding issues. Quaternary Science Reviews 24:595-629.

Turney, C.S.M., Kershaw, A.P., Clemens, S., Branch, N., Moss, P.T. and Fifield, L.K. 2004. Millennial and orbital variations in E1 Niño/Southern Oscillation and high latitude climate in the last glacial period. Nature 428:306-310.

Sniderman,J.M.K., O'Sullivan, P.B., Hollis, J. and Kershaw, A.P. 2004. Late Pliocene vegetation and climate change in the Western Uplands of Victoria, Australia. Proceedings, Royal Society 
of Victoria 116:79-94.

Pickett, E.J., Harrison, S.P., Hope, G., Harle, K., Dodson, J.R., Kershaw, A.P., Prentice, I.C., Backhouse, J., Colhoun, E.A., D’Costa, D., Flenley, J., Grindrod, J., Haberle, S.G., Hassell, C., Kenyon, C., Macphail, M., Martin, H., Martin, A.H., McKenzie, M., Newsome, J.C., Penny, D., Powell, J., Raine, J.I., Southern, W., Sutra, J.-P., Thomas, I., van der Kaars, S. and Ward, J. 2004. Pollen-based reconstructions of biome distributions for Australia, South East Asia and the Pacific (SEAPAC region) at 0, 6000 and 18,000 14C yr B.P. Journal of Biogeography 30:1381-1444.

Hope, G.S., Kershaw, A.P., van der Kaars, S., Sun, X., Liew, P-M., Heusser, L.E., Takahara, H., McGlone, M., Myoshi, N. and Moss, P.T. 2004. History of vegetation and habitat change in the Austral-Asian region. Quaternary International 118-119:103-126.

Kershaw, A.P., D'Costa, D.M., Tibby, J., Wagstaff, B.E. and Heijnis, H. 2004. The last million years around Lake Keilambete, western Victoria. Proceedings, Royal Society of Victoria 116:95-106.

Sherwood, J, Oyston, B. and Kershaw, A.P. 2004. The age and contemporary environments of Tower Hill volcano, southwest Victoria, Australia, Proceedings, Royal Society of Victoria 116:71-78.

Harle, K.J., Kershaw, A.P. and Clayton, E. 2004. Patterns of vegetation change in southwest Victoria (Australia) over the last two glacial/interglacial cycles. Proceedings, Royal Society of Victoria 116:107-139.

Kershaw, A.P., Tibby, J., Penny, D., Yesdani, H., Walkley, R., Cook, E. and Johnston, R. 2004. Latest Pleistocene and Holocene vegetation and environmental history of the western plains of Victoria. Proceedings, Royal Society of Victoria 116:141-163.

Anshari, G., Kershaw, A.P. and van der Kaars, S. 2004. Environmental Change and peatland forest dynamics in the Lake Sentarum Area, West Kalimantan, Indonesia. Journal of Quaternary Science 19:637-655.

Kershaw, A.P and Turney, C. 2004. The day after tomorrow. Australasian Science 25(7):29-31.

McKenzie, G.M. and Kershaw, A.P. 2004. A Holocene pollen record from cool temperate rainforest, Aire Crossing, the Otway region of Victoria, Australia. Review of Palaeobotany and Palynology 132:281-290.

Kershaw, A.P., van der Kaars, S. and Moss, P.T. 2003. Late Quaternary Milankovitch-scale climate change and variability and its impact on monsoonal Australia. Marine Geology 201:81-95.

Kershaw, A.P., Moss, P.T. and van der Kaars, S. 2003. Causes and consequences of long-term climatic variability on the Australian continent. Freshwater Biology 48:1274-1283.

Tibby, J., Reid, M.A., Fluin, J., Hart, B.T. and Kershaw, A.P. 2003. Assessing long-term pH change in an Australian river catchment using monitoring and palaeolimnological data. Environmental Science and Technology 37:3250-3255.

Reid, M.A., Fluin, J., Ogden, R.W., Tibby, J. and Kershaw, A.P. 2002. Long-term perspectives on human impacts on floodplain-river ecosystems, Murray-Darling Basin, Australia. Proceedings of the International Association of Theoretical and Applied Limnology 28:710-716.

Harle, K.J., Heijnis, H., Chisari, R., Kershaw, A.P., Zoppi, U. and Jacobsen, G. 2002. A chronology for the long pollen record from Lake Wangoom, western Victoria (Australia) as derived from uranium/thorium disequilibrium dating. Journal of Quaternary Science 17:707-720.

Turney, C.S.M., Bird, M.I., Fifield, L.K., Kershaw, A.P., Cresswell, R.G., Santos, G.M., di Tada, M.L., Hausladen, P.A. and Youping, Z. 2001. Development of a robust 14C chronology for Lynch's Crater (North Queensland, Australia) using different pretreatment strategies. Radiocarbon 43:45-54. 
Turney, C.S.M., Kershaw, A.P., Moss, P., Bird, M.I., Fifield, L.K., Cresswell, R.G., Santos, G.M., di Tada, M.L., Hausladen, P.A. and Youping, Z. 2001. Redating the onset of burning at Lynch's Crater (North Queensland): implications for human settlement in Australia. Journal of Quaternary Science 16:767-771.

Kershaw, A.P. and Wagstaff B.E. 2001. The southern conifer family Araucariaceae: history, status, and value for palaeoenvironmental reconstruction. Annual Review of Ecology and Systematics 32:397-414.

Anshari, G., Kershaw, A.P. and van der Kaars, S. 2001. A Late Pleistocene and Holocene pollen and charcoal record from peat swamp forest, Lake Sentarum Wildlife Reserve, West Kalimantan, Indonesia. Palaeogeography, Palaeoclimatology, Palaeoecology 171:213-228.

van der Kaars, S., Kershaw, A.P., Tapper, N., Moss, P. and Turney, C. 2001. Pollen records of the last glacial cycle in the Southern Hemisphere tropics of the PEPII transect. PAGES Nerws 9(2):11-12.

Wagstaff, B.E., Kershaw, A.P., O’Sullivan, P.B., Harle, K.J. and Edwards, J. 2001. An Early to Middle Pleistocene palynological record from the volcanic crater of Pejark Marsh, Western Plains of Victoria, southeastern Australia Quaternary International 83-85:211-232.

Kershaw, A.P. 2001. The history, palaeoclimatic significance and present day status of the southern conifer families Araucariaceae and Podocarpaceae, with special reference to Australia. Revista Universidade Guarulhos Geociencias 6:5-21.

Kershaw, A.P., Quilty, P.G., van Huet, S., David, B. and McMinn, A. 2000. The Quaternary. In Contributions to Phanerozoic Biogeography of Australasian Faunas and Floras. Australasian Association of Palacontologists Memoirs 23:461-506.

Bohte, A. and Kershaw, A.P. 1999. Taphonomic influences on the interpretation of the palaeoecological records from Lynch's Crater, northeastern Australia. Quaternary International 57/58:49-59.

Harle, K.J., Kershaw, A.P. and Heijnis, H. 1999. The contributions of uranium/thorium and marine palynology to the dating of the Lake Wangoom pollen record, Western Plains of Victoria, Australia. Quaternary International 57/58:25-35.

McKenzie, G.M. and Kershaw, A.P. 2000. The last glacial cycle from Wyelangta, the Otway Region of Victoria, Australia. Palaeogeography, Palaeoclimatology, Palaeoecology 155:177193.

Moss, P.T. and Kershaw, A.P. 2000. The last glacial cycle from the humid tropics of northeastern Australia: comparison of a terrestrial and a marine record. Palaeogeography, Palaeoclimatology, Palaeoecology 155:155-176.

van der Kaars, S., Wang, X., Kershaw, A.P., Guichard, F. and Setiabudi, D.A. 2000. Late Quaternary palaeoecological record from the Banda Sea, Indonesia: patterns of vegetation, climate and biomass burning in Indonesia and northern Australia. Palaeogeography, Palaeoclimatology, Palaeoecology 155:135-153.

Petit-Maire, N., Bouysse, P., de Beaulieu, J.-L., Boulton, G., Iriondo, M., Kershaw, P., Lisitsyna, O., Partridge, T., Pflaumann, U., Sarnthein, M., Schulz, H., Soons, J., van Vliet-Lanö, J., Yuan, B., Guo, Z. and van der Zijp, M. 2000. Geological records of the recent past, a key to the near future world environments. Episodes 23:230-246.

Wang, X., van der Kaars, S., Kershaw, A.P., Bird, M. and Jansen, F. 1999. A record of vegetation and climate through the last three glacial cycles from Lombok Ridge core G6-4, eastern Indian Ocean, Indonesia. Palaeogeography, Palaeoclimatology, Palaeoecology 147:241-256.

Kershaw, A.P. 1998. Estimates of regional climatic variation within southeastern Australia since the Last Glacial Maximum from pollen data. Palaeoclimates - Data and Modelling 3:107-134.

Kershaw, A.P., Moss, P.T. and van der Kaars, S. 1997. Environmental Change and the human 
occupation of Australia. Anthropologie 35/2:35-43.

Kershaw, A.P. 1997. A modification of the Troels-Smith system of sediment description and portrayal. Quaternary Australasia 15/2:63-68.

Lloyd, P.J. and Kershaw, A.P.1997.Late Quaternary vegetation and early Holocene quantitative climatic estimates from Morwell Swamp, Latrobe Valley, southeastern Australia.Australian Journal of Botany 45:549-563.

McKenzie, G.M. and Kershaw, A.P. 1997. A vegetation history and quantitative estimate of Holocene climate from Chapple Vale, the Otway region of Victoria, Australia. Australian Journal of Botany 45:565-581.

Jenkins, M.A. and Kershaw, A.P. 1997. A mid-late Holocene vegetation record from an interdunal swamp, Mornington Peninsula, Victoria. Proceedings of the Royal Society of Victoria 109:133-148.

Kershaw, A.P. 1997. A bioclimatic analysis of Early to Middle Miocene brown coal floras, Latrobe Valley, southeastern Australia. Australian Journal of Botany 45:373-387.

D'Costa, D.M. and Kershaw, A.P. 1997. An expanded recent pollen database from southeastern Australia and its potential for refinement of palaeoclimatic estimates. Australian Journal of Botany 45:583-605.

Kershaw, A.P. and Bulman, D. 1996. A preliminary application of the analogue approach to the interpretation of late Quaternary pollen spectra from southeastern Australia. Quaternary International 33:61-71.

Holdgate, G.R., Kershaw, A.P. and Sluiter, I.R.K. 1995. Sequence stratigraphic analysis and the origins of Tertiary brown coal lithotypes, Latrobe Valley, Gippsland Basin, Australia. International Journal of Coal Geology 28:249-275.

Sluiter, I.R.K., Kershaw, A.P., Holdgate, G.R. and Bulman, D. 1995. Biogeographic, ecological and stratigraphic relationships of the Miocene brown coal floras, Latrobe Valley, Victoria, Australia. International Journal of Coal Geology 28:277-302.

D'Costa, D. and Kershaw, A.P. 1995. A late Quaternary pollen record from Lake Terang, Western Plains of Victoria, Australia. Palaeogeography, Palaeoclimatology, Palaeoecology 113:57-67.

Kershaw, A.P. 1995. Environmental change in Greater Australia. Antiquity 69:656-675.

Kershaw, A.P. 1994. Pleistocene vegetation of the humid tropics of northeastern Queensland, Australia. Palaeogeography, Palaeoclimatology, Palaeoecology 109:399-412.

Crowley, G.M., Grindrod, J. and Kershaw, A.P. 1994. Modern pollen deposition in the tropical lowlands of northeast Queensland, Australia. Review of Palaeobotany and Palynology 83:299-327.

Kershaw, A.P. and Bulman, D. 1994. The relationship between modern pollen samples and environment in the humid tropics region of northeastern Australia. Review of Palaeobotany and Palynology 83:83-96.

Kershaw, A.P., Bulman, D. and Busby,J.R. 1994. An examination of modern and pre-European settlement pollen samples from southeastern Australia: assessment of their application to quantitative reconstruction of past vegetation and climate. Review of Palaeobotany and Palynology 82:83-96.

Crowley, G.M. and Kershaw, A.P. 1994. Late Quaternary environmental change and human impact around Lake Bolac, western Victoria, Australia. Journal of Quaternary Science 9:367377.

Kershaw, A.P. and Nanson, G.C. 1993. The last full glacial cycle in the Australian region. Global and Planetary Change 7:1-9.

Kershaw, A.P., McKenzie, G.M. and McMinn, A. 1993. A Quaternary vegetation history of northeast Queensland from pollen analysis of ODP Site 820. Proceedings of the Ocean 
Drilling Program 133:107-114.

Kershaw, A.P. 1993. Palynology, biostratigraphy, and human impact. The Artifact 16:12-18.

Harle, K.J., Kershaw, A.P., Macphail, M.K. and Neyland, M.G. 1993. Palaeoecological analysis of an isolated stand of Nothofagus cunninghamii (Hook.) Oerst. in eastern Tasmania. Australian Journal of Ecology 18:161-170.

Kershaw, A.P. 1993. Quantitative palaeoclimatic estimates from bioclimatic analyses of taxa recorded in pollen diagrams. Quaternary Australasia 11(1):61-64.

Aitken, D.L. and Kershaw, A.P. 1993. Holocene vegetation and environmental history of Cranbourne Botanic Garden. Proceedings of the Royal Society of Victoria 105:67-80.

Markgraf, V., Dodson, J.R., Kershaw, A.P., McGlone, M.S. and Nicholls, N. 1992. Evolution of late Pleistocene and Holocene climates in the circum-South Pacific land areas. Climate Dynamics 6:193-211.

Kershaw, A.P., Bolger, P., Sluiter, I.R., Baird,J. and Whitelaw, M. 1991. The origin and evolution of brown coal lithotypes in the Latrobe Valley, Victoria, Australia. International Journal of Coal Geology 18:233-249.

Kershaw, A.P., D'Costa, D.M., McEwen Mason, J. and Wagstaff, B.E. 1991. Quaternary vegetation of mainland southeastern Australia. Quaternary Science Reviezws 10:391-404.

Edney, P.A., Kershaw, A.P. and De Deckker,P.1990. A late Pleistocene and Holocene vegetation and environmental record from Lake Wangoom, Western Plains of Victoria, Australia. Palaeogeography, Palaeoclimatology, Palaeoecology 80:325-343.

Kershaw, A.P. and Strickland, K. 1990. A 10 year pollen trapping record from northeastern Australia. Review of Palaeobotany and Palynology 64:281-288.

Crowley, G.M., Anderson, P., Kershaw, A.P. and Grindrod, J. 1990. Palynology of a Holocene marine transgressive sequence, lower Mulgrave River Valley, north-east Queensland. Australian Journal of Ecology 15:231-240.

D'Costa, D.M., Edney, P.A., Kershaw, A.P. and De Deckker, P. 1989. The late Quaternary palaeoecology of Tower Hill, Victoria, Australia. Journal of Biogeography 16:461-482.

Bell, C.J.E., Finlayson, B.L. and Kershaw, A.P. 1989. Pollen analysis and dynamics of a peat deposit in Carnarvon National Park, central Queensland. Australian Journal of Ecology 14:449-456.

Kershaw, A.P. 1989. Was there a 'Great Australian Arid Period'? Search 20:89-92.

Kershaw, A.P and Nix, H.A. 1988. Quantitative palaeoclimatic estimates from pollen data using bioclimatic profiles of extant taxa. Journal of Biogeography 15:589-602.

Kershaw, A.P and Strickland, K.M. 1988. A Holocene pollen diagram from Northland, New Zealand. New Zealand Journal of Botany 26:145-152.

Kershaw, A.P. 1986. Climate change and Aboriginal burning in north-east Australia during the last two glacial/interglacial cycles. Nature 322:47-49.

Kershaw, A.P. 1985. An extended late Quaternary vegetation record from northeastern Queensland and its implications for the seasonal tropics of Australia, Proceedings, Ecological Society of Australia 13:179-189.

Kershaw, A.P., Edney, P., Peterson, J.A. and Coutts, P.J.F. 1985. Evidence of a Pleistocene age for Tower Hill, western Victoria, Search 16:302-303.

Kershaw, A.P.1983. A Holocene pollen diagram from Lynch's Crater, northeastern Queensland, Australia New Phytologist 94:669-682.

Kershaw, A.P. and Green, J.E. 1983. Tawonga Bog revisited: the history of a low altitude peat deposit. Victorian Naturalist 100:256-259.

Kershaw, A.P. 1983. Considerations nouvelles sur la flore et la vegetation Australienne. L'Espace Geographique 12:185-194.

Kershaw, A.P. 1983. Huon Pine, Australia's longest living tree, tells an epic story of survival. Habitat 11:32-34. 
Sluiter, I.R. and Kershaw, A.P. 1982. The nature of late Tertiary vegetation in Australia. Alcheringa 6:211-222.

Kershaw, A.P. and Sluiter, I.R. 1982. Late Cainozoic pollen spectra from the Atherton Tableland, northeastern Australia. Australian Journal of Botany 30:279-295.

Kershaw, A.P. and Sluiter, I.R. 1982. The application of pollen analysis to the elucidation of Latrobe Valley brown coal deposits and stratigraphy. Australian Coal Geology 4:169-186.

Kershaw, A.P. 1981. Climate and Australian flora. Australian Natural History 20:231-234.

Kershaw, A.P. 1980. An extension of the late Quaternary vegetation record from northeastern Australia. Fourth International Palynological Conference, Lucknow (1976-77) 3:28-35.

Hooley, A.D., Southern, W. and Kershaw, A.P. 1980. Holocene vegetation and environments of Sperm Whale Head, Victoria. Journal of Biogeography 7:349-362.

Kershaw, A.P. 1979. Local pollen deposition in aquatic sediments on the Atherton Tableland, north-eastern Australia. Australian Journal of Ecology 4:253-263.

Kershaw, A.P. 1979. The changing vegetation of northeastern Queensland. See Australia 2:152-154.

Kershaw, A.P. 1978. The analysis of aquatic vegetation on the Atherton Tableland, north-east Queensland, Australia. Australian Journal of Ecology 3:23-42.

Kershaw, A.P. 1978. Record of last glacial-interglacial cycle from northeastern Queensland. Nature 272:159-161.

Binder, R. and Kershaw, A.P. 1978. A late Quaternary pollen diagram from the southeastern highlands of Australia. Search 9:44-45.

Kershaw, A.P. 1977. The state of biogeographical research in Australia. Geography Teacher 17:5-11.

Kershaw, A.P. 1976. A late Pleistocene and Holocene pollen diagram from Lynch's Crater, northeastern Queensland, Australia. New Phytologist 77:469-498.

Kershaw, A.P. 1975. Stratigraphy and pollen analysis of Bromfield Swamp, northeastern Queensland, Australia. New Phytologist 75:173-191.

Kershaw, A.P. and Hyland, B.P.M. 1975. Pollen transfer and periodicity in a rainforest situation. Review of Palaeobotany and Palynology 19:129-138.

Kershaw, A.P. 1974. A long continuous pollen sequence from northeastern Australia. Nature 251:222-223.

Turner, J. and Kershaw, A.P. 1973. A late- and post-glacial pollen diagram from Cranberry Bog, near Beamish, County Durham. New Phytologist 72:915-928.

Kershaw, A.P. 1973. Quaternary history of rainforests in Australia. Wildlife in Australia 10:82-83.

Kershaw, A.P. 1971. A pollen diagram from Quincan Crater, north-east Queensland, Australia. New Phytologist 70:669-681.

Kershaw, A.P. 1970. Pollen morphological variation in the Casuarinaceae. Pollen et Spores 12:145-61.

Kershaw, A.P 1970. A pollen diagram from Lake Euramoo, north-east Queensland, Australia. New Phytologist 69:785-805. 